\title{
AS RELAÇÕES CIÊNCIA-TECNOLOGIA-SOCIEDADE E OS PRINCÍPIOS TEÓRICOS-ANALÍTICOS DOS ESTUDOS CTS
}

\section{LORYNE VIANA DE OLIVEIRA}

Instituto Federal de Brasília - Campus Estrutural

E-mail: loryne@ymail.com

\section{RESUMO}

Propõe-se um estudo sobre os sentidos das relações entre ciência, tecnologia e sociedade - CTS, a fim de sintetizar princípios teórico-analíticos do Movimento CTS. Duas perspectivas paralelas concorrem para tal: a reflexão conceitual sobre as inter-relações e como foram lidas historicamente. Procedeu-se à caracterização destas relações com o surgimento da técnica e sua dimensão ontológica nas idades antiga, moderna, e após a modernidade, com ênfase nos estudos sobre ciência, tecnologia e sociedade - ECTS, percorrendo o pensamento de Robert Merton, Thomas Kuhn, - Programa Forte da Sociologia do Conhecimento, o Programa Empírico do Relativismo e a Construção Social da Tecnologia, culminando no surgimento do Movimento CTS, no seio de segmentos sociais e a mudança nas atitudes públicas com relação à ciência e tecnologia na década de 1960 e com o florescer das reflexões CTS em países periféricos, sobretudo no contexto do Pensamento Latino Americano em CTS. Aponta para a centralidade e urgência destas discussões como ponto de partida para a participação social em assuntos de ciência e tecnologia e educação científica.

\section{PALAVRAS-CHAVE:}

CTS; Estudos Sociais da Ciência e Tecnologia.

SCIENCE-TECHNOLOGY-SOCIETY RELATIONS AND THE THEORETICAL-ANALYTICAL PRINCIPLES OF STS STUDIES

\section{ABSTRACT}

This article proposes to study the meanings of the relations between science, technology, and society - STS, to synthesize theoretical and analytical principles of the STS Movement. Two parallel perspectives contribute to this: a conceptual reflection on interrelationships and how they have been read historically. These relations were characterized by the emergence of the technique and its ontological dimension in the ancient, modern. Postmodern ages, with emphasis on the studies on science, technology, and society, traversing the thinking of Robert Merton, Thomas Kuhn, the Strong Program of Sociology of Knowledge, the Empirical Program of Relativism, and the Social Construction of Technology, culminating in the emergence of the STS Movement within social segments and the change in public attitudes toward science and technology in the 1960s and the flourishing of STS in peripheral countries, especially in the context of Latin American Thinking in STS. It points to these discussions' centrality and urgency as a starting point for social participation in matters of science and technology and scientific education.

\section{KEYWORDS:}

STS; STS studies. 


\section{INTRODUÇÃO}

A literatura acerca de ciência, tecnologia e sociedade, doravante CTS ${ }^{1}$, narra, univocamente, o surgimento do movimento Ciência, Tecnologia e Sociedade como tendo ocorrido nos Estados Unidos durante os anos 60 do século passado (CEREZO, 2003; AIKENHEAD, 1994a, 1994b, 2005; GARCIA et al.1996; SOLOMON, 1988). Entretanto, os ECTS - Estudos CTS -, podem ser entendidos como uma nova leitura que têm tomado lugar no curso das transformações históricas, sociais, econômicas, científicas e tecnológicas, vivenciadas de forma ainda mais intensa considerando a quantidade e velocidade de informação que circula em um mundo crescentemente globalizado cuja marca indelével é a própria dinâmica entre os elementos da tríade Ciência-Tecnologia-Sociedade.

Para trilhar este caminho propomos neste ensaio, a dilação da análise das relações CTS para um período anterior à ciência moderna, numa perspectiva ampliada que nos permita balizar a temática considerando sua natureza interdisciplinar em sua particularidade filosófica, posto que um dos desafios de nossa pesquisa maior requer escolher uma abordagem que nos permita delimitar ECTS como um campo de conhecimento não-homogêneo e dificilmente unificável, porém, possuindo um núcleo, mesmo que restrito, de consenso em seus pressupostos.

Pretendemos, portanto, lançar um breve olhar para estas relações ou mesmo para a sua elisão em alguns períodos da história das ideias a fim de resgatar de forma concisa os fundamentos histórico-ontológicos da relação entre ciência, tecnologia e sociedade e compreender seu desdobramento no tempo. Neste percurso será inevitável um trânsito constante entre filosofia e sociologia da ciência. Esperamos que

\footnotetext{
${ }^{1}$ Tomaremos aqui CTS para nos referir às relações entre os elementos da tríade, e ECTS ou ESCT - Estudos Sociais sobre CT para nos referirmos aos estudos acadêmicos sobre CTS. Quanto à expressão movimento CTS a usaremos para nos referir a situações de intervenção social através de reivindicações ou interesse de mudança específicos (cf. VACCAREZZA, 2011; VON LISINGEN, 2007). 
a partir destes entendimentos possamos finalmente sintetizar princípios teóricos e analíticos dos ECTS e perceber suas implicações no nosso contexto sócio histórico através do Pensamento Latino Americano sobre CTS - PLACTS.

\section{UM OLHAR DESDE ANTES: DA ANTIGUIDADE À MODERNIDADE E ALÉM}

O mito de Prometeu, informado por Ésquilo e Hesíodo, traz a representação da condição humana entre a dor e a sabedoria. O titã, protetor da humanidade ainda ignorante e sofredora, fornece aos homens o fogo, que simbolicamente corresponde às artes e técnicas, de forma a ensejar uma existência mais inteligente e projetiva², potencialmente dotada de conhecimento para a vida. Por fim, Prometeu atribui ao homem um "espírito-criador" (JAEGER, 2001). Com a posse de tal lote divino o homem, o animal mais indefeso e inerme de toda a criação conforme Platão (Prot., 321 c), se vê apto a sobreviver. Em resposta ao furto cometido por Prometeu, Zeus pune também aos homens os enviando Pandora, portadora de todas as mazelas das quais padece a humanidade.

A consciência mítica arrola ainda outras narrativas que enfocam a aspiração de transcender os limites da condição humana por meio da relação com a técnica e com a tecnologia. É o caso da história da fuga de Dédalo e Ícaro do labirinto do Minotauro. Nela, Ícaro, em desobediência aos conselhos do pai, acaba voando alto demais, comprometendo as asas artificiais que seu Dédalo havia projetado.

No curso da história, o vínculo do homem com a natureza começa a se destacar há cerca de 2,5 milhões de anos, quando se inicia o emprego de artefatos que intermediam ou mesmo suprimem o contato imediato com o mundo. A idade da pedra, a despeito de sua rudimentaridade em relação a todas ferramentas envolvidas inaugura uma relação de proximidade entre o conhecimento da physis ou natureza, que se dá numa relação profundamente ritualizada e mítica em povos arcaicos e tem

${ }^{2}$ AZAMBUJA, C. C. (2013). Prometeu: a sabedoria pelo trabalho e pela dor. Archai, n. 10, jan-jul, p. 19-28. 
outros desdobramentos ao longo da história. A ruptura completa com o mundo natural no qual o humano se insere não é factível, ou seja, ciência e tecnologia compõem a cultura na qual florescem e para qual contribuem (MITCHAM, 1999).

A trajetória da relação entre ciência, tecnologia e sociedade, portanto, acompanha a história do empreendimento humano e de sua diferenciação do mundo natural através do emprego da técnica, mesmo que rudimentar, para atingir o intento de sobrevivência através da transformação da natureza. Em certo sentido, "para que qualquer grupo humano sobreviva, é indispensável certo grau de desenvolvimento da técnica, e a sobrevivência e o bem-estar de grupos humanos cada vez maiores são condicionados pelo desenvolvimento dos meios técnicos" (ABBAGNANO, 2007, p. 940). A relação entre o mundo natural e o mundo humano "foi complementada e em certa medida, posta de lado por nossa aliança à artefatos. A natureza foi substituída pelo artefato como mundo imediato em que todos vivemos, nos movemos e existimos" (MITCHAM, 1999, p. 128, tradução nossa).

De forma simplificada, Mitcham (1989) elenca três períodos distintos quanto a forma de compreender as relações CTS: (1) a visão pré-moderna, para a qual CTS são separadas e não sofrem influência mútua e para a qual Ciência e Tecnologia (doravante CT) são controladas pela sociedade ou pelo Estado; (2) a visão moderna, que alude relações entre CT e sociedade, sobretudo para proclamar a autonomia e neutralidade desta esfera; e (3) a visão pós-moderna, na qual se encontra o movimento CTS constituído como uma terceira via, que em um pluralismo de vertentes que rechaçam o estabelecimento de relações simplistas entre Ciência, Tecnologia e Sociedade.

Na visão pré-moderna importa que a ciência detinha seu ideal no saber de tipo teórico, em detrimento do fazer cotidiano, prático ou produtivo. Esta divisão entre os conhecimentos humanos é feita por Aristóteles em Ética a Nicômaco: o conhecimento teórico (episteme) seria aquele especulativo, contemplativo, abstrato, que discute 
aspectos gerais de objetos independentes da interferência humana, enquanto os práticos (práxis) e produtivos (poiesis) se referem à aplicação imediata e efetiva de um problema específico.

O conhecimento produtivo difere do prático por envolver a ação fabricadora, articulando um conjunto de técnicas para compor uma obra ou objeto, envolvendo, portanto, um produto material externo ao agente. Quanto ao conhecimento prático, se refere ao campo da ação humana, porém têm fim em si mesmo a exemplo da ética e da política. Apesar de reunir a característica contemplativa, o conhecimento teórico, antecessor da ciência moderna, não era racionalista em sentido estrito como viria a ser mais tarde (MITCHAM, 1989).

Neste período, o nascimento da filosofia na Grécia Antiga representa uma abordagem diferente para os fenômenos naturais, desvinculando-se de explicações mágicas e míticas. Neste momento, filosofia e ciência são ainda indistintas. Enquanto no Egito Antigo conhecimentos práticos permitiam o emprego de técnicas de agrimensura para controlar as terras que eram inundadas pelas águas do Nilo, os gregos são os primeiros a transpor este conhecimento aplicado, empírico por meio de demonstrações teóricas. Em certo sentido, a physis, a qual os filósofos pré-socráticos ${ }^{3}$, dedicaram suas investigações, até então ponto de partida para o saber produtivo, passa a originar o saber epistemológico, ou seja, inaugura categorias racionais (REALE, 1990) próprias e distintas das demais formas disponíveis em outras civilizações

\footnotetext{
${ }^{3}$ O pensamento pré-socrático se diferencia não apenas com relação a seu entendimento acerca da natureza do mundo, mas também na sua forma de explicar o que é possível, de uma forma que os seus antecessores falharam em ver e compreender. Heráclito aponta que os mitólogos precedentes, Hesíodo, Xenófanes, Pitágoras e Hecateu não sucederam em apreender o significado mais profundo dos fatos disponíveis devido a seus conhecimentos serem isolados e parcelados. A própria noção de cosmologia, que sucede a cosmogonia, implica em um arranjo ordenado do que existe, exigindo portanto, um conhecimento deste mundo deve ser ordenado. Quanto aos pré-socráticos milesianos, seus ímpetos em mensurar e explicar fenômenos terrestres e celestes eram equivalentes a investigações abstratas acerca de causas e princípios subjacentes à matéria (ALGRA, 1999; WHITE, 2002 e 2008 apud CURD, 2016). 
contemporâneas aos gregos e que se distinguiu de explicações míticas e buscou causas para tecer teorias coerentes ${ }^{4}$.

Ainda sobre a visão clássica sobre a relação entre ciência e tecnologia, Platão em A República,manifesta a preocupação de que a atividade produtiva ligada às técnicas, artesanais e tecnologias pudesse ameaçar a concretização de virtudes mais elevadas na ordem social. O artesão corria o risco de ater-se ao ideal de controlar a vida ao invés de vivê-la. Já em As Leis (III, 677-679), ao discutir a questão das técnicas, Platão exprime desilusão com seu uso enquanto constata um fatal declínio da humanidade.

Além de separadas, ciência enquanto episteme e tecnologia enquanto saber produtivo ou poiesis, ambas seriam governadas pela sociedade. Sintetiza-se esta proposição tomando por referência Aristóteles, em Ética à Nicômaco (2007), onde a política é apresentada como arte fim, tendo primazia sobre as demais. Isto é, é no âmbito da política que se define o que se deve fazer ou deixar de fazer:

Ora, a política mostra ser dessa natureza, pois é ela que determina quais as ciências que devem ser estudadas num Estado, quais são as que cada cidadão deve aprender, e até que ponto; e vemos que até as faculdades tidas em maior apreço, como a estratégia, a economia e a retórica, estão sujeitas a ela. Ora, como a política utiliza as demais ciências e, por outro lado, legisla sobre o que devemos e o que não devemos fazer, a finalidade dessa ciência deve abranger as das outras, de modo que essa finalidade será o bem humano. Com efeito, ainda que tal fim seja o mesmo tanto para o indivíduo como para o Estado, o deste último parece ser algo maior e mais completo, quer a atingir, quer a preservar. (ARISTÓTELES, 2007, p.2)

Para compreender a produção cultural de um povo também deve-se atentar para a organização social, as condições de produção da existência material e relações

\footnotetext{
${ }^{4}$ No contexto da Grécia Arcaica, a tradição e a memória eram transmitidos oralmente por meio de poemas baseados em mitos, estes eram histórias verdadeiras que revelam a origem real do mundo e dos seres humanos. Hodiernamente associa-se o mito a uma crença popular amplamente difundida, algo que deve ser desmascarado como sendo falso. No século VII a.C surgem discursos naturalistas alternativos ao mítico-poético: o histórico e o filosófico. O próprio Platão nega a dualidade estrita entre mito e filosofia quando opta por usar mitos tradicionais e propor novos mitos (p.ex., o Mito da Caverna, ou o Mito do Anel de Giges) para incutir conceitos filosóficos e os ensinar tópicos que fossem de difícil apreensão (cf. PARTENIE, 2014). 
de produção vigentes, pelo que a Grécia Antiga, escravista, reafirmava a desvalorização do trabalho manual e da técnica patente no pensamento de seus pensadores frente à atividade intelectual de especulação e contemplação, a quem se dedicavam os nobres (ARANHA e MARTINS, 2004).

Durante o período medieval, com relação a CT no ocidente cristão, há avanços técnicos-engenheiros como catapultas de contrapeso, canhões e trabucos (MEDINA, 2008), mas pouca mudança é observada: CT permanecem cindidas neste período, cujo mote é a religião ao invés da política. A concepção clássica de menosprezo para com a prática e técnica se avulta no período da Idade Média, quando as atividades manuais se realizam pelos servos da gleba, papel de menor prestígio em uma sociedade regida por relações de vassalagem.

A ciência moderna do século XVII se desvincula definitivamente da filosofia pela adoção de um método e de um objeto específicos. A assim chamada revolução científica, extensão da nova ordem burguesa instaurada no contexto do desenvolvimento da indústria nascitura, irá representar uma ruptura em muitos sentidos (FOUREZ, 1995).

Primeiramente, a religião, central no pensamento medieval ocidental, é suplantada pelo poder da razão e pela primazia do método científico. A investigação científica é modelada neste período sobretudo a partir da contribuição de Galileu na astronomia e física, a partir da observação, experimentação e matematização (PESSANHA, 1987). É possível ilustrar este raciocínio de Galileu (1987, p. 130):

A filosofia encontra-se escrita neste grande livro que continuamente se abre perante nossos olhos (isto é, o universo), que não se pode compreender antes de entender a língua e conhecer os caracteres com os quais está escrito. Ele está escrito em língua matemática, os caracteres são triângulos, circunferências e outras figuras geométricas, sem cujos meios é impossível entender humanamente as palavras; sem eles nós vagamos perdidos dentro de um obscuro labirinto. (GALILEU, 1987, p. 130) 
A teoria de Galileu desbanca o geocentrismo ptolomaico aceito por mais de vinte séculos, representa não apenas uma revolução científica, mas também a ruptura com uma construção estética e cosmológica, implicando em uma perda do "próprio mundo em que vivia e pensava, e teve de transformar e substituir não só seus conceitos e atributos fundamentais, mas até mesmo o quadro de referência de seu pensamento" (KOYRÉ, 1979, p.6).

Um fato importante é sua perseguição e consequente condenação pela Inquisição em razão de suas teorias que marcaram a derrocada de uma ordem cosmológica e espiritual anterior de aspiração aristotélica. Aspectos centrais do pensamento moderno, que possuem desdobramentos fundamentais emergem neste contexto, a exemplo do que pontuam Mariconda e Lacey (2001, p. 50):

A ideia de que a ciência é "livre de valores" pode ser reconduzida à emergência da distinção entre fato e valor no século XVII. Pode-se considerar que essa ideia tem três componentes: imparcialidade, neutralidade e autonomia. Mostramos que partes importantes dessas idéias componentes foram desenvolvidas e defendidas por Galileu, principalmente em suas cartas a Castelli e à grã-duquesa Cristina e em seus livros $O$ ensaiador e Diálogo sobre os dois máximos sistemas do mundo. O argumento de Galileu em favor da autonomia é particularmente poderoso e, embora não tenha a generalidade introduzida por argumentos posteriores (uma vez que seu principal objetivo era o de garantir a autonomia da ciência com relação à autoridade da Igreja), permanece no cerne de todas as defesas subseqüentes da autonomia da ciência. Esse argumento está baseado em três suposições: que o entendimento científico está sujeito a critérios que são independentes da autoridade da Igreja e de qualquer perspectiva de valor; que os cientistas cultivam as virtudes do "ethos científico"; e que (porque usam linguagens diferentes - o argumento dos "dois livros") não pode existir contradição entre os juízos científicos apropriados e as declarações da Igreja. Finalmente, algumas limitações dos argumentos de Galileu são indicadas, sem serem desenvolvidas (MARICONDA; LACEY, 2001, p. 50).

O processo histórico que garantiu a prevalência da ideia de autonomia da ciência teve início na disputa de Galileu pela teoria heliocêntrica, afinal, emancipar a ciência da religião exigia emancipá-la também de setores opostos à Igreja. 
O caso de Galileu é paradigmático enquanto representante desta nova institucionalidade entre CT: artefatos tecnológicos como o telescópio foram centrais para uso de instrumental e realização de experimentos, logo, a modernidade enquanto renascimento científico representa a ruptura com a visão clássica por apregoar que CT devem andar juntas, se retroalimentando e influenciando reciprocamente, e devem ainda, ser autônomas e livre de valores.

É também neste período que se passa a olhar para relações entre CT como promissoras, beneméritas e positivas, afinal, a aliança entre ambas viabiliza grandes avanços científicos (MITCHAM, 1989). Anteriormente a relação com o conhecimento era de observação, contemplação e não manipulação: a tecnologia disponível anteriormente era funcional no sentido de construir modelos, sendo que na modernidade passa a ser empregada para realizar experimentos (MITCHAM, 1989).

O próprio conhecimento oriundo do emprego de tecnologia se desdobra em aplicações tecnológicas, a exemplo da lei de queda dos corpos de Galileu, cuja matematização viabiliza a otimização técnica, por exemplo, na construção de canhões (MITCHAM, 1989). Ou seja, através da associação entre ciência e técnica foi possível realizar o ideal de Francis Bacon (1561-1626), estas passam a compor a concepção do que nos distingue dos demais animais: o homem é aquele que domina a natureza, aquele que a transforma. Ao associar ciência ao poder e controle da natureza, Bacon antevê o impacto que o pretenso domínio do homem sobre a natureza traria para a humanidade. A tecnologia ela mesma neste contexto pode ser entendida como aperfeiçoamento da técnica orientada pelo saber científico 5 .

\footnotetext{
${ }^{5}$ Neste momento adotaremos a perspectiva segundo a qual a técnica é um conhecimento empírico, que em decorrência da observação, prescreve um conjunto de procedimentos práticos para agir sobre as coisas. A tecnologia, porém, é um saber teórico que se aplica praticamente (CHAUÍ, 2003). Adiante retornaremos a analisar este tópico. 
O ideal baconiano de "saber é poder" se expressa como um modelo do novo

sistema político: a tecnocracia, caracterizada pelo exercício do poder político pelos que possuem conhecimento. Medina (2008, p. 5, tradução nossa) compara:

A posse do poder natural é o que legitima para o exercício do poder político de forma não democrática. Por mais que se acentuam as diferenças entre a legitimação política antiga e moderna da expertocracia da política, ambas seguem o mesmo esquema baseado nos privilégios políticos que um conhecimento superior minoritário confere aos experts. Na Antiguidade a capacidade política era radicada nas virtudes políticas teóricas, enquanto na modernidade, nas capacidades científicas operativas (MEDINA, 2008, p. 5, tradução nossa).

O desdobramento da modernidade faz com que a ciência deixe de fazer parte de um corpo de conhecimento teórico-contemplativo e se torne ativa subsidiária da técnica. No século seguinte, conhecido como "Século das Luzes", o conhecimento passa a ter caráter emancipatório, mas prevalece uma ciência não mais como instrumento neutro, mas a serviço de fins que ultrapassam seu valor. O debate sobre a relação entre o sistema de produção e a $\mathrm{CT}$, por intermédio do conceito de razão instrumental ${ }^{6}$ (FREITAG, 1986), está presente nas discussões da Escola de Frankfurt. É esta a leitura de Habermas $^{7}$ (1984, p. 453, apud FREITAG, 1995, p. 160) que sintetiza o projeto da modernidade:

O projeto da modernidade, formulado pelos filósofos do iluminismo no século 18, consiste em desenvolver, de maneira imperturbável, as ciências objetivas, a base universalista da moral e do direito, e a arte autônoma, respeitando as respectivas lógicas. Ao mesmo tempo insiste em revelar os potenciais cognitivos, que vão se acumulando, liberando-as de suas formas esotéricas, para utilizá-las nas práxis, ou seja, para uma estruturação racional das condições de vida (HABERMAS, 1984, p. 453, apud FREITAG, 1995, p. 160).

\footnotetext{
${ }^{6}$ A razão instrumental é majoritariamente técnica, empregada na organização das forças produtivas, objetiva aumentar a produtividade e competitividade, se opondo à razão vital, referente ao mundo das experiências pessoais e da comunicação entre as pessoas (cf. Freitag, 1986).

7 A "modernidade" refere-se às formações societárias do "nosso tempo", dos "tempos modernos". O início da "modernidade" está marcado por três eventos históricos ocorridos na Europa e cujos efeitos se propagaram pelo mundo: a Reforma Protestante, o lluminismo ("die Aufkärung) e a Revolução Francesa. Em outras palavras, a "modernidade" se situa no tempo. Ela abrange, historicamente, as transformações societárias ocorridas nos séculos 18, 19 e 20, no "Ocidente". Neste sentido, ela também se situa no espaço: seu berço indubitavelmente é a Europa. Seus efeitos propagam-se posteriormente pelo hemisfério norte, especialmente pelos países do Atlântico Norte. 
O projeto da modernidade, inacabado, envolve um compromisso em sintetizar CT e tornar a política sua subordinada. Em uma perspectiva crítica a modernidade deve ser reavaliada, uma vez que gera múltiplas formas de alienação, criando novos problemas ao tentar oferecer solução para os antigos e alterando os limites da natureza pelos limites do artefato, circunscrevendo a conquista da natureza preconizada por Bacon, Descartes, entre outros, à uma esfera de incerteza quanto à capacidade de desvendar a natureza e transformar a condição humana através da técnica, como assevera Silva (1997, p.11):

Em princípio, nenhum elemento haveria neste quadro que pudesse causar estranheza ao homem do nosso século, habituado às conquistas tecnológicas derivadas do progresso da ciência e à marcha acelerada que caracteriza o domínio da terra por via das criações do engenho humano. Entretanto, se nos detivéssemos numa análise mais precisa deste pensamento que se constituiu na alvorada dos tempos modernos, duas coisas poderiam talvez causar inquietação. A primeira é o caráter utópico de certas propostas de organização social do trabalho científico que acompanham e mesmo ilustram a pretensão de domínio racional. Em Bacon, textos como a NovaAtlântida descrevem, na forma da utopia, uma civilização extremamente equilibrada, totalmente calcada na busca e organização do saber em todos os domínios, do que resulta o estado de felicidade desfrutado por todos os habitantes. O segundo motivo de inquietação deriva da maneira como Descartes pretendia integrar as várias partes que compõem a totalidade unitária do saber humano, definindo a vinculação do empreendimento teórico com as suas aplicações práticas através do termo sabedoria. A esta perfeita integração entre a teoria e a prática é assinalado o mesmo objetivo proposto por Bacon: a consecução da felicidade humana. Os ramos extremos da árvore que em Descartes representa o sistema do saber são a mecânica, a medicina e a moral, o que nos indica que o saber teórico se complementa na sua aplicação harmônica às três dimensões que concorrem, no ser humano, para a felicidade: o domínio técnico da natureza pelas artes mecânicas, a extinção das doenças e o prolongamento da vida e finalmente o domínio interno das paixões que deve levar à serenidade do espírito. (SILVA, 1997, p.11)

Ou seja, a modernidade é composta por um jogo de forças baseado na visão de CT como um bem irrestrito, absoluto, sendo autônomas e independentes da sociedade. Este jogo de forças, cujo equilíbrio é posto em xeque atualmente, apresenta limitações inquestionáveis. Enquanto o conhecimento científico é 
transformado através da tecnologia por uma miríade de especializações, crescentemente abstratas, a tecnologia aprimorada pela ciência leva a dicotomias expressas em conquistas e mazelas que vêm à tona em momentos históricos como a Revolução Industrial (MITCHAM, 1989).

As relações CTS na pós-modernidade buscam explicitar as formas nem sempre ostensivas pelas quais CT estiveram sob influência perene de ingerências sociais ou religiosas, e se expressam em uma pluralidade complexa, que guarda em comum apenas o rechaço a monismos simplistas da CT. De acordo com Mitcham (1989), a proposta pós-moderna de superação da modernidade reside em duas proposições: (a) CT devem estar em alguma medida separadas e não devem determinar uma à outra; e (b) CT em alguma medida devem ser governadas pela sociedade ou por políticas. Destarte, os estudos CTS (ECTS) correlacionam um novo jogo de forças, tendente a criticar o projeto da modernidade, reavaliando o presente.

Enquanto filósofos pós-estruturalistas como Jacques Derrida (1930-2004) e Michel Foucault (1926-1984), fora do espectro formal dos ECTS, irão ressaltar uma necessidade de rejeição da modernidade para ir além dela. Freitag (1995) resume que por eles "a razão é desmascarada como vontade de dominação objetivada nas estruturas da sociedade", e portanto, conclui Freitag (1995, p.153):

Não existe, nessa vertente filosófica, ação voltada para o entendimento, para a solidariedade. Toda ação é exercício de poder, controle, repressão, tendo como aliado o saber (= razão instrumental). A modernidade ("sistema" e "mundo vivido") é desmascarada como o império da razão instrumental (vontade de dominação). Com seu desmascaramento pela filosofia tem início uma nova era, a pós-modernidade, que rejeita a razão e instaura o império da desrazão. (FREITAG, 995, p.153)

A Escola de Frankfurt rejeita o ideal de progresso e o enxerga como adjacente à razão em seu formato moderno: o culto à razão, cujo ápice é o positivismo desconsidera a opressão e desumanização a ela subjacentes, o que implica na "perda da autonomia do sujeito, docilizado tanto pela sociedade industrial totalmente 
administrada como pelas extremas regressões à barbárie representada pelos Estados totalitários"(ARANHA e MARTINS, 2004, p.151). Um dos expoentes desse pensamento é Hebert Marcuse ${ }^{8}$, que rejeitava a ciência moderna, cujo pensamento, em contraposição ao de Jürgen Habermas, se esgota na crítica.

Por outro lado e ainda às voltas com o projeto da modernidade, Habermas (1980) encara a especialização excessiva das ciências uma fragilidade e irá propor a categorização de modelos decisórios para CT e a sociedade: o tecnocrático - no qual o caráter social e histórico do conhecimento científico é desconsiderado e a autoridade do especialista impõe primazia na definição de diretrizes; o decisionista - para o qual a voz do especialista comparece de forma a intermediar o processo decisório, ou seja, ele auxilia na consecução de objetivos nomeados socialmente; e o pragmático - o mais democrático de todos, fundado no diálogo e negociação permanentes entre os atores envolvidos, o que torna as decisões fundamentalmente políticas.

Em suma, CT não são mais aceitas como formas privilegiadas de conhecimento, havendo um esforço em direção à promoção de formas democráticas, ecletismo cultural e descentralização política. Nesse panorama, o movimento CTS converge para um espaço no qual se viabiliza a promoção de afinidades entre campos científicos diversos e interdisciplinares, resistentes a reducionismos, portanto, "criativo e com papel potencialmente formativo na busca por uma percepção pós-moderna de ciência, tecnologia e sociedade"(MITCHAM, 1989, p.413).

\section{UM OLHAR SÓCIO-HISTÓRICO PARA A CIÊNCIA: O FUNCIONALISMO MERTONIANO E OS PARADIGMAS DE KUHN}

Na alvorada do século XIX a história e filosofia da ciência assistem à consolidação do paradigma cientificista, com o apogeu de tendências positivistas. De forma concisa, o positivismo é uma forma radical de empirismo, porquanto valoriza as ciências

${ }^{8}$ Cf. A ideologia da sociedade industrial: o homem unidimensional. 
naturais por seu recurso ao observável, mensurável, conversível em dados positivos. A unidade da ciência, uma das teses desta escola de pensamento, decorria do fato de que o conhecimento deve constituir um todo coerente, assim como a recusa à metafísica.

Auguste Comte (1798-1857), pioneiro desta escola, divide em 3 os estágios de desenvolvimento do homem: (a) mítico ou fictício: ocorre entre povos primitivos e é caracterizado por atribuir a causa dos fenômenos naturais à agentes sobrenaturais; (b) metafísico: embora racional, ainda envolve a tentativa de explicar o mundo em virtude de uma causa primeira, que pode incluir abstrações personificadas como artifício explicativo; e (c) científico ou positivo, no qual surge a figura do cientista. Sobre este último Comte (1978, p. 4) explica que:

[...] o espírito humano, reconhecendo a impossibilidade de obter ações absolutas, renuncia a procurar a origem e o destino do universo, a conhecer as causas íntimas dos fenômenos, para preocupar-se unicamente em descobrir, graças ao uso bem combinado do raciocínio e da observação, suas leis efetivas, a saber, suas relações invariáveis de sucessão e similitude. A explicação dos fatos, reduzida então a seus termos reais, se resume de agora em diante na ligação estabelecida entre os diversos fenômenos particulares e alguns fatos gerais, cujo número o progresso da ciência tende cada vez mais a diminuir (COMTE,1978, p. 4).

Com o positivismo a ciência se consolida enquanto instância independente e autônoma e é reforçada enquanto forma superior de conhecimento. Esta escola, uma das grandes correntes filosóficas do século XIX, tem um de seus desdobramentos mais sofisticados, o Positivismo Lógico, que se desenvolve na alvorada do século XX no contexto dos encontros do Círculo de Viena, cujo principal expoente foi Rudolf Carnap (1891-1970), que tinha como principais teses o critério empirista do significado ${ }^{9}$,

\footnotetext{
${ }^{9}$ Popper (1974) e Russell (1971) criticaram sobretudo a primeira das teses: se sentido e método de verificação são idênticos, as leis das ciências naturais seriam inverificáveis e tornariam frases aceitáveis absurdas. Em especial para o primeiro, o conceito positivista de "significado» ou "sentido» (ou de verificabilidade, confirmabilidade indutiva, etc) não é apropriado para realizar a demarcação entre ciência e metafísica, simplesmente porque a metafísica não é necessariamente carente de sentido, embora não seja uma ciência. (POPPER, 1974, p. 281). Popper elege como critério de demarcação a falseabilidade, segundo a qual a teoria deve ser clara o suficiente para que possa ser falseada, ou seja, provada falsa com base em observações e experimentos. 
segundo o qual o sentido de uma frase empírica é seu método de verificação, e a circunscrição do pensamento lógico a um processo não criativo de transformações tautológicas. Karl Popper (1902-1994), muito embora não se filie diretamente ao Círculo, com ele guarda bastante proximidade, seja pelo diálogo, seja pelo fato de, em conjunto com Carnap (1992), representar a corrente da concepção herdada de ciência (TRIGUEIRO, 2012). A concepção herdada de ciência é aquela para a qual (CEREZO et al., 2003, p 15):

O desenvolvimento científico é concebido deste modo como um processo regulado por um rígido código de racionalidade autônomo, alheio a condicionantes externas (sociais, políticas, psicológicas...). Em situações de incertezas, por exemplo, diante da alternativa de dois desenvolvimentos teóricos igualmente aceitáveis em um dado momento (baseado na evidência empírica), tal autonomia seria preservada, apelando-se para algum critério meta-científico igualmente objetivo. Virtudes cognitivas quase sempre invocadas em tais casos são as da simplicidade, do poder preditivo, da fertilidade teórica e do poder explicativo. [...] Mais ainda, a ciência mesma, com sua diversidade de disciplinas, era contemplada como um grande sistema axiomático cujos conceitos e postulados básicos eram os da física matemática. A chamada lógica de predicados de primeira ordem com identidade se supunha poder oferecer o instrumental requerido para formalizar tais sistemas, ou melhor, para fundamentá-los e proporcionar uma compreensão rigorosa dos mesmos. (CEREZO et al., 2003, p.15)

Enquanto isso, é no século XX que as meta-ciências começam a questionar o cientificismo e a ideia de desenvolvimento temporal deste corpo de conhecimento como linear e cumulativo, em outras palavras, como paradigma de progresso humano (CEREZO et al., 2003). Conforme nos lembra Premebida e colaboradores (2011, p. 25), "nas décadas de 1950 e 1960, os ECTS se caracterizam pelo estudo da estrutura, mudanças e organização da comunidade científica, da cientometria e do papel dos cientistas na sociedade". É o momento em que a ciência deixa de ser discutida apenas de um ponto de vista conceitual para ser discutida a partir de sua construção social. 
A sociologia da ciência emergente na virada do século XIX para o XX ${ }^{10}$, tem seu

percurso clássico desde o funcionalismo de Robert Merton, a perspectiva histórica de Thomas Kuhn, o Programa Forte da sociologia do conhecimento até os construtivistas Bruno Latour, Karin e Steve Woolgar ${ }^{11}$.

Merton (1910-2003), em seu principal trabalho, Ciência, Tecnologia e Sociedade na Inglaterra do Século XVII de 1938, se debruça sobre as causas da institucionalização da ciência. Para ele, a guinada tecnológica relacionada à intensificação do comércio, protoindustrialização e sucessão de conflitos militares, compõem o contexto técnico do surgimento da ciência moderna, colocando sempre fatores exógenos como necessários e inseparáveis para a compreensão da ciência (MARCOVICH; SHINN, 2013).

Merton, portanto, encerra-se às origens da ciência, seu ethos, ou seja, sem mencionar questões cognitivas. Em 1942 em A ciência e as estrutura social democrática surgem os imperativos institucionais da ciência, quais sejam: (a) comunismo: os conhecimentos científicos não estão sujeitos à propriedade intelectual, sendo um bem da comunidade científica; (b) universalismo: os critérios da ciência são impessoais e pré-estabelecidos e a aceitação ou rejeição de alegações científicas não devem depender dos atributos pessoais ou sociais do seu proponente (MERTON, 2013); (c) desinteresse: diria respeito ao padrão distintivo de controle de uma gama de motivos que caracterizaria o comportamento de cientistas (MERTON, 2013); (d) ceticismo organizado, princípio metodológico-institucional segundo o qual

\footnotetext{
${ }^{10}$ Como antecedentes na sociologia do conhecimento pode-se citar Max Scheler (1874-1928), Karl Mannheim (18931947) e Ludwik Fleck (1896-1961), embora este último tenha tido suas ideias permanecido pouco exploradas até recentemente.

11 Também há relevantes pensadores de ascendência marxista como Boris Hessen, John Desmond Bernal e Joseph Needham, que irão compor a corrente externalista, para a qual os conteúdos científicos são demandados pelas forças produtivas vigente, sendo preponderante e condutora do desenvolvimento da CT. Os Princípia de Newton são analisados por Hessen (1992), no qual discute a relação entre o desenvolvimento de ideias científicas com demandas econômico-produtivas. Esta corrente já em 1931 durante o II Congresso Internacional de História das Ciências e das Tecnologias em Londres já se manifestava denunciando a influência da sociedade no desenvolvimento da CT, embora "trabalhos dessa época não considerassem a possibilidade de interferência de fatores externos no conteúdo científico propriamente dito" (CUNHA, 2008).
} 
o julgamento deve permanecer suspenso até que se disponha de fatos comprobatórios.

Outra contribuição importante de Merton ao analisar processos psicossociológicos que afetam a designação de recompensas aos cientistas por suas contribuições, por ele chamado por Efeito Mateus, era oriunda do reconhecimento por parte de seus pares, e que pesquisadores de renome tendiam a continuar recebendo reconhecimento cumulativo (MARCOVICH; SHINN, 2013). Com isto Merton revoluciona ${ }^{12}$ ao estabelecer como eixo de seu trabalho a ciência enquanto instituição social, pensa a comunidade científica e suas regras de funcionamento no mesmo patamar que qualquer outra instituição: a legitimação de teorias passa por outros fatores além de cognitivos e epistemológicos.

O funcionalismo mertoniano irá manter a sociologia da ciência adstrita à sociologia do conhecimento, ou seja, de alguma forma não irá adentrar o âmbito do conhecimento científico propriamente dito. Isto é, a sociologia se confina à investigação histórica de descobertas científicas e análise das instituições que dão suporte à atividade científica/trabalho dos cientistas.

A natureza especial do conhecimento científico em si não era objeto de análise até então, sendo a ciência orientada por suas próprias determinações, resta o estudo da funcionalidade das instituições para o livre curso do progresso científico (PALÁCIOS, 1994). A tradição funcionalista mantinha intacta a primazia da filosofia da ciência no trato com as questões relativas ao teor do conhecimento científico. A superação desta fronteira só se dará mais tarde com o programa forte da sociologia do conhecimento, representado principalmente por David Bloor, na década de 70 em Edimburgo.

\footnotetext{
${ }_{12}$ Merton iniciou seu trabalho aos auspícios de Parsons (1902-1979), sendo tributário em alguma medida do estruturofuncionalismo daquele ao mesmo tempo que se distingue. Para Parsons (1937, apud MARCOVITCH; SHINN, 2013), todas relações sociais são expressões de requisitos funcionais positivos, ou seja, concebe a sociedade como um todo, que mantém entre suas partes e as interações entre elas dão conta de sua manutenção e funcionamento, portanto, forma um sistema social (ESQUINA; TORRES, 2009). 
Ainda nos anos 60 do século XX, a escola historicista, representada por Thomas Kuhn, Imre Lakatos e Larry Laudan, irá se contrapor à visão simplista de ciência, propondo uma perspectiva histórica ao se olhar para as teorias científicas, ou seja, teorias científicas não são um conjunto de enunciados e axiomas, mas sim uma estrutura de conceitos que evoluem historicamente, tanto inter-teoricamente quanto intra-teoricamente.

A reflexão de Kuhn (1922-1996) trará conceitos importantes para compreender a dinâmica complexa das revoluções científica: o primeiro deles é o de paradigma, que se refere a crenças, valores, técnicas partilhadas pelos membros de uma comunidade científica, bem como as soluções concretas, modelos, exemplos empregados na resolução de problemas (KUHN, 2003). Paradigmas se sucedem ao longo da história das ciências, sendo incomensuráveis entre si, ou seja: adotam linguagens diversas e não redutíveis entre si para formular enunciados em cada uma das teorias.

Com a divisão entre ciência normal - período no qual há na comunidade científica prevalência de um paradigma sendo a pesquisa firmemente baseada em uma ou mais realizações passadas (KUHN, 2003); e ciência revolucionária - períodos de revolução científica e crise, nos quais há a substituição de paradigmas incompatíveis entre si, com a finalidade de dissolver anomalias (violações das expectativas paradigmáticas que governam a ciência normal), Kuhn atesta que o contexto histórico é imprescindível para o desenvolvimento das teorias e seu acolhimento pela comunidade científica. O trabalho de Kuhn não ganhou muita notoriedade na filosofia da ciência, enquanto teve grande impacto na sociologia da ciência ${ }^{13}$, muito embora seu trabalho desbanque a ideia de progresso sistemático na ciência e seja seminal para a percepção da dimensão social e do enraizamento

\footnotetext{
${ }^{13}$ Pode-se deduzir que isto se deve ao fato de que Kuhn em certa medida rompeu o monopólio disciplinar que a filosofia da ciência exercia sobre questões epistemológicas da ciência, já que sua análise ancorada na sociologia e na história tinha por foco as noções de racionalidade e progresso científicos (DUARTE, 2007). 
histórico da ciência, situando-se na interseção dos conhecimentos interdisciplinares, o que prepara o terreno para os estudos sociais da ciência e tecnologia (CEREZO et al., 2003).

\section{OS ESTUDOS SOCIAIS DA CIÊNCIA E TECNOLOGIA: O PROGRAMA FORTE DA SOCIOLOGIA DO CONHECIMENTO E ABORDAGENS CONTEMPORÂNEAS}

Charles Percy Snow, em palestra seminal proferida em maio de 1959 em Cambridge, e subsequentemente publicada como As duas culturas e uma segunda leitura, trouxe à baila a dicotomia por ele nomeada como duas culturas, denunciando a cisão entre os acadêmicos da literatura e das ciências. Para ele, há uma ruptura entre a cultura humanista e científica. Para Snow (1959, p. 26), "os humanistas não conhecem conceitos básicos da ciência, enquanto os cientistas não tomam conhecimento das dimensões psicológicas, sociais e éticas dos problemas científicos".

Nesta esteira surge em Edimburgo, Escócia em 1964, o Science Studies Unit, "um departamento voltado para realizar estudos interdisciplinares a respeito da atividade científica com intuito de fornecer aos estudantes de engenharia uma formação científica que transcendesse as fronteiras entre as diversas disciplinas" (DUARTE, 2007, p. 11).

Um impulso crucial para os Estudos Sociais da Ciência e Tecnologia surge a partir das atividades de tal departamento. Foi o Programa Forte da Sociologia do Conhecimento, do qual são expoentes o supracitado David Bloor e também Barry Barnes. Após Kuhn em 1962 haver, com A Estrutura das Revoluções Científicas ${ }^{14}$ aberto o espaço da racionalidade científica para a análise sociológica, o Programa Forte da Sociologia do Conhecimento irá além do que fez Merton nas décadas de 40 a 60, no sentido de avaliar não apenas a ciência enquanto instituição e seu

\footnotetext{
${ }^{14}$ No breve estudo que pretendemos aqui empreender, tomaremos como referência para tratar do Programa Forte as formulações de Bloor em Knowledge and Social Imagery. 
funcionamento, mas o próprio teor do conhecimento científico para esta escola também será objeto de análise.

Ou seja: o conhecimento e consequentemente a ciência, deixa de ser o sacro fruto de um método detalhadamente aplicado no sentido anteriormente conferido por filósofos modernos, algo que necessariamente deve poder ser falseado conforme Popper (1974) ou algo extremamente restritivo como queria o critério empirista de significado dos positivistas lógicos. No contexto de Bloor e do Programa Forte, o conhecimento é simplesmente o corpo de crenças aceito pela coletividade como tendo poder explicativo. A este respeito nos explica Duarte (2007, p. 42) que:

[...] uma determinada pessoa de uma dada sociedade não pode simplesmente mudar as formas cognitivas socialmente sancionadas a seu bel-prazer. Pelo contrário, o conhecimento de uma sociedade só pode ser alterado a partir de processos sociais (DUARTE, 2007, p. 42).

De forma imediata, esta interpretação eleva a sociologia ao status de metaciência por excelência, de forma que os critérios para escolha de uma teoria em detrimento de outra está diretamente ligado a causas sociais que permeiam determinada comunidade científica. Os princípios programáticos do Programa Forte (BLOOR, 1991, p.7) são: (a) causalidade: as crenças dos cientistas são causadas socialmente e não racionalmente; (b) imparcialidade: as causas sociais devem explicar tanto o sucesso quanto o fracasso de teorias científicas; (c) simetria ${ }^{15}$ : as mesmas causas devem explicar tanto teorias racionais quanto irracionais; e (d) reflexividade: a sociologia da ciência também deve obedecer aos preceitos do programa.

\footnotetext{
${ }^{15}$ Este princípio foi formulado com intuito de não recorrer a fatores racionais para explicar o sucesso de algumas teorias e à fatores sociais/psicológicos para explicar o fracasso de outras (DUARTE, 2007), dito de outra forma, todas as explicações do desenvolvimento científico devem ser simétricas, ou seja, os vencidos e vencedores da história da ciência. Nas palavras de Latour e Woolgar (1997, p. 23), “ou as explicações sociais e psicológicas, econômicas são usadas apenas para explicar por que um cientista se enganou, e então elas não têm valor, ou devem ser empregadas simetricamente, de modo a explicar porque esse cientista errou e porque aquele outro acertou". Ou como afirma Latour e Woolgar (op. cit, p.23): “Fazer sociologia para compreender por que os franceses acreditam na astrologia, mas não para compreender por que eles acreditam na astronomia, isso é assimétrico".
} 
Em suma, o Programa Forte radicalizou a desconstrução do cientificismo, que se eximia de qualquer caráter normativo, muito comum no contexto da filosofia da ciência, para adotar um caráter descritivo da atividade científica. A crítica ao Programa Forte, a exemplo de Laudan (1984 apud DUARTE, 2007), diz que os princípios programáticos orientadores desta escola não refletem o modo de proceder das outras ciências como queria Bloor.

Há diversos desdobramentos do Programa Forte, não sendo possível os listar todos extensiva e detalhadamente ${ }^{16}$, focaremos o trabalho de Bruno Latour e Steve Woolgar, com a etnografia e Harry Collins com o Programa Empírico do Relativismo EPOR, no acrônimo inglês.

Em certa medida tributários do Programa Forte ${ }^{17}$, os construtivistas de abordagem etnográfica, Bruno Latour e Steve Woolgar, publicam Vida de Laboratório em 1979, com a proposta de estudar a ciência do ponto de vista sociológico, porém, sem deixar separar contexto social e conteúdo científico e sem recurso à metalinguagem que recobre o que os atores dizem e fazem na prática. Inovam frente à perspectiva historiográfica kuhniana e sociológica anterior que usava como material de análise material textual, ao ir "a campo" com a perspectiva de investigar as práticas de laboratório de uma comunidade científica específica. Adotam um enfoque microsocial para entender objetos com os quais cientistas trabalham, como se produz a ciência, tomada como sendo a construção de enunciados e de argumentação persuasiva sobre sua validade.

Latour e Woolgar (1997), portanto colocam que o fato científico é construído socialmente e tomado como natural num processo de elisão da sua forma de

\footnotetext{
${ }^{16}$ Os estudos de reflexividade e a teoria da rede de atores, representada por Michel Callon, bem como as análises de Pierre Bourdieu não comporão o foco de nosso quadro de pesquisa, a despeito de sua relevância.

${ }^{17}$ Latour e Woolgar (1997, p. 22-24) entendem que a proposta de estudar etnograficamente um laboratório é prolongar o Programa Forte de Bloor, pois leva às últimas consequências alguns de seus princípios a exemplo do princípio da simetria, o ampliando para além de tratar simetricamente os vencidos e vencedores em ciência, para tratar ainda simetricamente natureza e sociedade. 
produção, de forma que depende estratégias e procedimentos no sentido de eliminar os vestígios da trajetória na qual ele foi produzido. Tal processo, que culmina na construção de um fato científico, obedece a noções estabelecidas e confrontadas com os dados obtidos via etnografia, quais sejam: (a) inscrição literária: materialização dos objetos de estudo da ciência, registrados através de instrumentos, que conferem realidade às entidades estudadas ${ }^{18}$ pelos cientistas; (b) enunciados: articulados em consonância com as inscrições obtidas, enunciados buscam articular especulações em fatos instituídos, visando persuadir acerca de sua correção; (c) construção do fato científico: se dá com o apagamento do referencial histórico, considerando a flutuação da facticidade dos enunciados.

Latour e Woolgar nos auxiliam a compreender aspectos de nossa própria cultura que tomamos como estabelecidos e subsidiariamente, produzir novidades sobre a ciência a partir da descrição etnográfica ${ }^{19}$ detalhada da dinâmica do laboratório.

Desta forma, "o estudo etnográfico do laboratório constitui ocasião para investigar a atividade científica como prática social especialmente pertinente ao propósito de gerar informações sobre os processos sociais de raciocínio e argumentação em geral” (KROPF; FERREIRA, 1998, p. 591). Neste processo, ambos levam às últimas consequências alguns princípios do Programa Forte da Sociologia do Conhecimento, a exemplo do doravante profícuo princípio da simetria, ampliando-o

\footnotetext{
${ }^{18}$ Kropf e Ferreira (op. cit.) sobre esta noção de Latour e Woolgar que "uma vez obtidas as inscrições, rapidamente são esquecidos os procedimentos e etapas circunstanciais que conduziram à sua produção, sendo estes então relegados ao domínio da "pura técnica". Dessa forma, alcança-se o efeito de considerar o fenômeno em questão um objeto "natural", dotado de uma realidade prévia e totalmente independente. "

${ }^{19}$ Etnografia é uma abordagem de investigação científica oriunda da antropologia, caracterizada por longos períodos de observação e por "preocupar-se com uma análise holística ou dialética da cultura, introduzir os atores sociais com uma participação ativa e dinâmica e modificadora das estruturas sociais e preocupar-se em revelar as relações e interações significativas de modo a desenvolver a reflexividade sobre a ação de pesquisar, tanto pelo pesquisador quanto pelo pesquisado" (MATTOS, 2011).
} 
para além de tratar simetricamente os vencidos e vencedores em ciência, para tratar ainda simetricamente natureza e sociedade.

Quanto ao Programa Empírico do Relativismo desenvolvido nas décadas de 70 e 80, a ênfase dos trabalhos reside na construção sociológica empírica de controvérsias científicas. Collins (2009 e 2011), um de seus principais expoentes, busca reestruturar o pensamento e o discurso sobre a ciência, considerando a fragilidade epistemológica e política da concepção essencialista herdada da forma tradicional de pensar o conhecimento científico. Tomando por base sobretudo os princípios de simetria e reflexividade, o EPOR busca deslocar sua análise da ciência "enquanto fornecedora de verdades para uma análise do significado da expertise sobre a qual reside a prática da ciência e da tecnologia" (COLLINS e EVANS, 2009). A este respeito, nos informa Rigolin (2016, sem página):

Collins realizou estudos empíricos tanto sobre as "Ciências Duras" (TEA-laser, detecção de ondas gravitacionais), quanto em áreas marginais, como a Parapsicologia. Nestes estudos, observou os núcleos de peritos (core sets) para determinar como eles lidam com o problema de flexibilidade interpretativa dos mecanismos de fechamento de uma controvérsia (closure mechanisms). A flexibilidade interpretativa corresponde à ideia de que os resultados de experiências científicas podem ser interpretados de diferentes maneiras, o que tem reflexo nos mecanismos de encerramento: os debates na ciência não são encerrados estritamente com base em evidências, já que esta é contestada. Portanto, é preciso buscar as explicações em fatores micro-sociológicos (RIGOLIN, 2016, sem página).

O EPOR parte, portanto, das etapas: (a) mostrar a flexibilidade interpretativa dos resultados experimentais; (b) revelar mecanismos sociais, retóricos, institucionais entre outros que favorecem a promoção do consenso sobre a "verdade científica" frente a controvérsias e (c) relacionar estas formas de fechamento de controvérsias científicas com meios socioculturais e políticos mais amplos (CEREZO, 2003).

Na mesma linha está a concepção da construção social da tecnologia (Social Construction of Technology - SCOT), que representado por Trevor Pinch e Wiebe Bijker em meados da década de 1980 irá, em continuidade ao trabalho de Collins (1981) 
frente ao EPOR, aplicar o princípio da simetria à análise do desenvolvimento de artefatos tecnológicos. Em linhas gerais, o SCOT pretende dar um passo além da sociologia da ciência, rumo à sociologia da tecnologia. Em suma, conforme Pinch e Bijker e Pinch (1989, p. 28, tradução nossa):

No SCOT o processo de desenvolvimento de um artefato tecnológico é descrito como uma alternância entre variação de seleção. Isso resulta em um modelo "multidirecional", ao contrário dos modelos lineares usados explicitamente em estudos sobre inovação e implicitamente em muito da história da tecnologia. A visão multidirecional é essencial para qualquer construtivismo social da tecnologia. Obviamente em uma retrospectiva histórica é possível reduzir o modelo multidirecional a um modelo linear simples; mas com prejuízo para a fiabilidade do argumento de que estágios "bem-sucedidos" no desenvolvimento tecnológico não são os únicos possíveis.

Ou seja, o processo de seleção de um artefato é determinado pela forma que as variantes (no sentido de desenvolvimentos alternativos) afetam cada grupo social de usuários e sua influência no desenvolvimento de protótipos em um processo social que acomete o progresso científico-tecnológico ${ }^{20}$. O principal mérito do SCOT é, portanto, sua desconstrução do determinismo tecnológico subjacente à concepção tradicional do desenvolvimento tecnológico (CEREZO, 2003).

A variedade de abordagens nos Estudos Sociais da Ciência e Tecnologia expressa na microssociologia, relativismo, estudo de controvérsias e etnometodologia aperfeiçoaram e adequaram a visão de que dispúnhamos sobre a CT de forma geral, ao olhar numa perspectiva microssociológica e com apoio de estudos de caso, a produção de conhecimento e de artefatos, a dinâmica da atividade científica como se dá na prática, no laboratório ou no desenvolvimento tecnológico em sua complexidade social, em uma caracterização dentro do campo da cultura.

${ }^{20}$ A este respeito, cf. Bijker e Pinch (1989), aplicando o SCOT para tratar do desenvolvimento da bicicleta. 


\section{UM PASSO PARA FORA DA ACADEMIA: O MOVIMENTO CTS NO ÂMBITO SOCIAL}

Desenhada a controvérsia mais ampla, é necessário compreender como ocorre a percepção das relações CTS pelos segmentos sociais e a mudança nas atitudes públicas com relação a $\mathrm{CT}$, para além de como se materializa em meios acadêmicos e formulações teóricas. No período pós Segunda Guerra, que presenciou o nascimento dos primeiros computadores eletrônicos (1946), o primeiro transplante de órgãos (1950), o primeiro uso de energia nuclear para transportes (1954) e a invenção da pílula contraceptiva (1955), um grande otimismo circundava o desenvolvimento da CT (CEREZO, 2003).

A expressão mais contundente deste otimismo foi oriunda do discurso do diretor da Agência Norte Americana para Pesquisa Científica e Desenvolvimento, Vannevar Bush, que no relatório intitulado Ciência, a Fronteira inalcançável sintetiza o modelo linear de desenvolvimento, para o qual uma política de CT que financie a área de $P \& D$, sobretudo na ciência básica, respeitando sua autonomia traz, irrevogavelmente, crescimento econômico e consequentemente, bem-estar social. É o que o trecho abaixo pontua, a favor de uma política laissez-faire na CT (BUSH, 1945, tradução nossa):

Uma das nossas esperanças é que após a guerra haverá pleno emprego. Para atingir esse objetivo, as energias criativas e produtivas do povo americano devem ser liberadas. Para criar mais empregos, devemos criar produtos novos, melhores e mais baratos. Queremos muitas empresas novas e vigorosas. Mas novos produtos e processos não nascem prontos. Eles se apoiam em novos princípios e novas concepções que, por sua vez, resultam da pesquisa científica básica. A pesquisa científica básica é um capital científico. Além disso, não podemos mais depender da Europa como principal fonte desse capital científico. Claramente, mais e melhor pesquisa científica é um essencial para a consecução do nosso objetivo de pleno emprego.

As décadas posteriores presenciaram crescentemente o descrédito e o malestar pela ciência cuja prosperidade prometida, sobretudo para a classe trabalhadora, não se realizou. Neste sentido, são expressivos no contexto norte-americano do 
período alguns movimentos sociais encabeçados por grupos de ativistas, cuja pauta foi marcada por questões de direitos civis, meio ambiente e de consumo (CUTCLIFFE, 1990). Garcia e colaboradores (1996) ao discutir a cronologia de fatos que levaram à deflagração do movimento CTS em âmbito social elencam: o acirramento de tensões internacionais decorrentes da Guerra Fria ${ }^{21}$ como propulsora do desenvolvimento científico, também marcado por acidentes com energia nuclear ${ }^{22}$, e outras decorrências de conflitos bélicos na guerra do Vietnã ${ }^{23}$.

Destacam-se o movimento contracultura, movimento social definido como antisistema que se valia da mobilização em torno de tais questões e promovia a contestação social. A efervescência dos engajamentos sociais da época encontrou o ponto de ebulição também na ascensão dos Panteras Negras e na morte de Martin Luther King.

No mesmo ano em que Thomas S. Kuhn tem Estrutura das Revoluções Científicas publicado, Rachel Carson publica Primavera Silenciosa, best seller foi seminal para a emergência do movimento ambientalista e para a atenção social que receberão as questões científicas na década.

Nele a autora denuncia as consequências deletérias do uso de pesticidas na agricultura, nomeadamente o DDT (sigla de dicloro-difenil-tricloroetano), responsável pelo comprometimento do ciclo reprodutivo de aves, sendo bioacumulável ao longo da cadeia alimentar, situação cujo risco e impactos ambientais e ecológicos torna-se incalculável. No contexto norte-americano, a obra fez parte de um cenário no qual foi deflagrada uma situação de atenção para os resultados do desenvolvimento científico-

\footnotetext{
${ }^{21}$ O lançamento do primeiro satélite artificial pela URSS em 1957, o Sputinik, influenciou a criação em 1958 da Agência Aeroespacial Norte-Americana - NASA, e da Organização de Pesquisa Espacial Europeia - ESQR (precursora da ESA Agência Espacial Europeia.

${ }^{22} \mathrm{Em} 1957$ há dois acidentes: um nos Montes Urais na antiga URSS, em que um depósito nuclear explode, e outro na Inglaterra, onde um acidente num reator nuclear acaba propalando uma nuvem radioativa em direção à Europa Ocidental. Novamente em 1979, o Acidente em Three Mile Island com reatores nucleares somente será superado por Chernobyl (1986) e Fukushima (2011).

${ }^{23}$ Uso de napalm e outros métodos bélicos extremamente cruéis em larga escala. 
tecnológico. Faz parte deste cenário também a questão da Talidomida, medicamento sedativo amplamente prescrito para gestantes cujo uso indiscriminado ocasionou centenas de malformações congênitas em nascituros na década de 50.

Isto posto, as esferas sociais e políticas se voltaram para a regulação da CT e revogação da política do laissez-faire com relação à CT. O movimento CTS, portanto, é uma resposta no âmbito acadêmico, que compreende as articulações sócio-políticas, acadêmicas e educacionais em resposta à percepção de ingênua da CT orientadora de modelos clássicos de gestão política. Por percepção ingênua destaca-se a atinência à concepção herdada da natureza da ciência, discutida nas seções anteriores no campo do paradigma positivista ${ }^{24}$, tributário da modernidade.

Apesar de recente, o campo de estudos CTS se encontra consolidado, heterogeneamente disposto e interdisciplinar por natureza. É o que relatam Cerezo e colaboradores (2003, p. 126):

O aspecto mais inovador deste novo enfoque se encontra na caracterização social dos fatores responsáveis pela mudança científica. Propõe-se em geral entender a ciência-tecnologia não como um processo ou atividade autônoma que segue uma lógica interna de desenvolvimento em seu funcionamento ótimo (resultante da aplicação de um método cognitivo e um código de conduta), mas sim como um processo ou produto inerentemente social onde os elementos não-epistêmicos ou técnicos (por exemplo: valores morais, convicções religiosas, interesses profissionais, pressões econômicas etc.) desempenham um papel decisivo na gênese e na consolidação das ideias científicas e dos artefatos tecnológicos (CEREZO et al., 2003, p. 126).

O desenvolvimento dos estudos sobre as relações CTS em áreas de concentração: (a) acadêmico, já especificado enquanto matriz de pensamento dos ECTS; (b) políticas públicas, hasteando a bandeira de uma regulação social da CT em

\footnotetext{
${ }^{24}$ Há dois sentidos importantes em que o paradigma positivista é central para a concepção herdada de ciência, que mais tarde alimenta a concepção clássica das relações CTS e do modelo linear de desenvolvimento. A primeira delas é a noção de progresso, radicada no positivismo de ascendência cotidiana: torna-se numa crença constitutiva da percepção de história e também da própria noção da tecnociência, já que, em certo sentido o progresso se dá através desta e com sentido claramente ascencionário. A segunda é centrada no positivismo lógico já desenvolvido anteriormente neste texto, com ênfase na crença de que o conhecimento científico respeita um método com estrutura de lógica dedutiva rígida acrescido da avaliação empírica das hipóteses, o que implica em uma ciência que se desdobra sem apelo a valores não-epistêmicos ou cognitivos.
} 
detrimento de um modelo tecnocrata de tomada de decisão e (c) educação, promovendo um olhar para as possibilidades de difusão de uma nova imagem de CT a nível secundário e universitário, bem como em espaços não formais da educação científica. Estas ditas áreas de concentração se articulam em torno do "silogismo CTS" (CEREZO et al. 2003, p. 127):

o desenvolvimento científico-tecnológico é um processo social conformado por fatores culturais, políticos e econômicos, além de epistêmicos;a mudança científico-tecnológica é um fator determinante principal que contribui para modelar nossas formas de vida e de ordenamento institucional; constitui um assunto público de primeira magnitude;compartilhamos um compromisso democrático básico; portanto, deveríamos promover a avaliação e controle social do desenvolvimento científico-tecnológico, o que significa construir as bases educativas para uma participação social formada, assim como criar os mecanismos institucionais para tornar possível tal participação (CEREZO et al. 2003, p. 127).

Este silogismo sintetiza os frutos dos estudos acadêmicos, tradicionalmente associados aos estudos desenvolvidos na Europa (dos quais EPOR e SCOT seriam exemplos) e o desejo pela construção de um modelo democrático de gestão da CT, associados às reivindicações de movimentos sociais bem como o estudo das consequências sociais e ambientais da CT.

Garcia e colaboradores (1996, apud STRIEDER, 2012, p. 25) listam como sendo o núcleo comum dos programas CTS "o rechaço da imagem de ciência como atividade pura e neutra; a crítica à concepção de tecnologia como ciência aplicada e neutra; a promoção da participação pública na tomada de decisão".

Cerezo e colaboradores (2003), bem como Garcia e colaboradores (1996) e Medina, Sanmartín e colaboradores (1990) contemplam desdobramentos e reflexões empreendidos desde o contexto norte americano ou europeu. Mas a influência dos ECTS se estendem para além dos países do eixo norte, na América Latina o Pensamento Latino-Americano em CTS - PLACTS empreende uma reflexão contextualizada, considerando a particularidade do desenvolvimento dos países fora deste eixo. Este será objeto de análise a seguir. 


\section{O PENSAMENTO LATINO AMERICANO EM CIÊNCIA, TECNOLOGIA E SOCIEDADE}

A CT no contexto da América Latina possui como marcas indeléveis o autoritarismo, o obscurantismo ideológico e a instabilidade política. Soma-se a isso o parco, senão irrisório investimento em CT que se faz na região. Há que se destacar a defasagem em relação aos países desenvolvidos: a totalidade dos gastos na América Latina com ciência equivale a menos da metade do que investe a General Motors em P \& D (VACCAREZZA, 2011).

A atualidade brasileira corrobora de forma pujante esta realidade: do orçamento geral da União ${ }^{25}$ executado em 2015, apenas 0,27\% foi destinado a ciência e tecnologia em $2015^{26}$. Naturalmente estes números refletem na participação destas atividades no Produto Interno Bruto destes países, com números pouco representativos que giram em torno de 0,5\%, enquanto para países de capitalismo avançado o percentual gira em torno de 3\% (VACCAREZZA, 2011).

Um olhar histórico nos faz entender que prevalecia, anteriormente à década de 1960 na região, uma visão de que melhorias sociais iriam ocorrer naturalmente caso a autonomia da ciência fosse respeitada com total liberdade do critério interno de eficácia técnica, sustentada pela vigência do paradigma tecnocientocrata. Varsavsky (1978), pontua estas características como sendo atinentes ao cientificismo e gerando uma ciência dependente, preocupada com problemas de uma comunidade internacional em detrimento dos problemas locais.

O foco da produção científica na América Latina estava nos interesses da comunidade científica internacional, resultando numa atividade científica

\footnotetext{
${ }^{25}$ Outras características marcantes da realidade latino americana são: (a) a forma de financiamento de pesquisas em $P \& D$ - majoritariamente público, enquanto nos países centrais este índice é dividido com o setor empresarial, chegando a atingir 2/3 de capital privado para $1 / 3$ apenas de capital público; e (b) o número de doutores por mil habitantes, que enquanto nos Estados Unidos é 8,4 na Alemanha 15,4, no Brasil é apenas 1,4 (BRASIL, 2010, p. 23).

${ }^{26}$ Dados provenientes do levantamento feito pela Auditoria Cidadã da Dívida. Disponível em http://www.auditoriacidada.org.br/blog/2013/08/30/numeros-da-divida/. 
endogerada, mas exodirigida (SUÁREZ, 1973), caracterizada pelo uso da razão instrumental aliada à crença na neutralidade do observador, e na objetividade do conhecimento produzido acerca da realidade natural e social.

Já as décadas de 1970 e 1980 na região assistiram à predileção pela ciência pura em detrimento das tecnologias associadas com redução expressiva da função reguladora estatal no período, denotado pela abertura estatal promovida pelos princípios neoliberais presentes no momento (NASCIMENTO et. al., 2010). O capital internacional passa a pressionar por um desenvolvimento científico orientado para a inovação tecnológica, o que legitimou a ênfase maior à pesquisa básica para o desenvolvimento de novas tecnologias.

A década de 90 em diante é marcada pela reavaliação da relação entre ciência, tecnologia e sociedade, que embora não seja alheia às evidentes dissonâncias entre a produção científica e as necessidades sociais, opta por aderir ao modelo linear desenvolvimentista segundo o qual mais ciência implica em mais tecnologia, que leva ao crescimento econômico do país favorecendo a inclusão social pelo consumo. É a importação do modelo linear de desenvolvimento ou modelo ofertista, segundo o qual os resultados da investigação científica básica sempre se convertem em desenvolvimento tecnológico, que por sua vez conduz ao desenvolvimento social.

Há um sentido importante que torna este modelo linear ainda menos realista no contexto latino americano, culturalmente dependente. É o que salienta Vaccarezza (2011, p. 49):

[...] a dependência cultural da ciência latino-americana não assegura necessariamente a consequência esperada; pelo contrário, alimentou ainda mais o círculo de dependência econômica e atraso social. Em contraste com isso, foi necessário estabelecer a "demanda nacional de ciência e tecnologia" no âmbito de "projetos nacionais" que definissem as políticas de ciência e tecnologia. A este respeito, os conceitos de políticas de "ciência" e políticas de "ciência" foram peças-chave da análise. O ditador exclusivo do primeiro, destinado ao desenvolvimento de condições favoráveis e recursos para pesquisas científicas e tecnológicas, pressupõe uma abordagem linear 
conforme descrito. Os segundos sugerem que a capacidade científica deve visar favorecer realizações transferíveis para a sociedade e, portanto, exigir uma orientação explícita da pesquisa científica em relação aos problemas de aplicação. (VACCAREZZA, 2011, p. 49)

Os ECTS surgidos nos países centrais tiveram processos ou ligados ao ambiente acadêmico das ciências humanas - como foi o caso da Europa, representada pelo EPOR e SCOT, ou oriundos de movimento sociais opositores ao investimento de recursos públicos de $P \& D$ à indústria bélica e outros contextos com consequências negativas.

Na América Latina, de forma precedente e independente (DAGNINO, 2015), os ECTS nascem na Argentina, que a despeito do escasso apoio estatal, pela década de 1960 havia conquistado um posto de prestígio no cenário internacional com pesquisas científicas bastante relevantes. Como supracitado, neste período era adotado nos países periféricos o mesmo modelo linear de desenvolvimento de CT vigente nos países centrais.

O desenvolvimentismo, aceito por unanimidade nos debates na arena econômica, apregoava a prioridade da industrialização nacional de países periféricos. Na esfera acadêmica, a discussão era transposta de forma a buscar suprir conhecimentos necessários ao processo de industrialização, na qual polarizavam-se os argumentos de que era necessário buscar uma independência em matéria de CT, e de que seria mais vantajoso fazer uma importação de CT. Dagnino (2015, p. 49) relata:

Foi no interior dessa [primeira] posição que professores argentinos das ciências duras que queriam fazer pesquisa e não encontravam as condições para tanto que nasceu o PLACTS. Seu argumento central nesse debate era de que o justo apoio que demandava a comunidade de pesquisa supunha um Projeto Nacional que radicalizasse o componente democrático popular do nacional-desenvolvimentismo e contivesse, por isto, um desafio científico tecnológico original. (DAGNINO, 2015, p. 49)

Dentro deste panorama histórico, o Pensamento Latino Americano sobre CTS PLACTS de forma interdisciplinar, reunindo pesquisadores de diferentes áreas, muito embora ainda sem formar uma comunidade consciente auto identificada como CTS, 
em torno sobretudo de refletir sobre CT como uma competência das políticas públicas (VACCAREZZA, 2011).

O surgimento do PLACTS, portanto, busca lançar um olhar interdisciplinar e crítico para políticas de CT nascidas nos contextos norte americano e europeu, transferidas para a realidade sul americana, o que resultou na criação de comissões e conselhos setoriais específicos para CT, cujas atribuições se concentravam na formulação de planejamentos próprios, realização de diagnósticos e desenvolvimento de instrumentos de gestão.

A reflexão se dava partindo da própria experiência enquanto pesquisadores e economistas, estes últimos também responsáveis encampar as compreensões sobre CT através da Comissão Econômica para América Latina e Caribe - $C E P A L^{27}$, órgão associado à Organização das Nações Unidas - ONU. Alguns representantes deste pensamento são os argentinos Amílcar Herrera (1971, 1973), Jorge Sábato (1982), Óscar Varsavsky (1971, 1978), e mais especificamente no contexto brasileiro contemporâneo Baumgarten (2008) e Dagnino (2003, 2007 e 2008).

Amilcar Herrera (1920-1994), discute, por exemplo, que o impacto das novas tecnologias nos países periféricos foi muito diferente do que os benefícios alcançados pelos países centrais. Nos primeiros, a despeito do crescimento econômico apenas uma minoria privilegiada tem acesso a estes benefícios, e a maioria da população não vive em condições muito melhores do que as que encontrava antes do começo do processo de modernização.

Para Herrera (1982), o desafio no campo científico e tecnológico dos países em desenvolvimento é superior ao de países centrais ${ }^{28}$. Os países centrais têm sistemas

27 A CEPAL gestou grande parte do Pensamento Desenvolvimentista Latino Americano, para o qual a origem do subdesenvolvimento dos países sul americanos se devia a uma fraca industrialização, e deveria ser superado para que os países pudessem atingir o patamar de desenvolvimento ideal. A este respeito, cf. Raul Prebischem em $O$ desenvolvimento econômico da América Latina e alguns de seus principais problemas, de 1949.

${ }^{28}$ A terminologia empregada originalmente por Herrera é de países de terceiro mundo. 
de P\&D muito avançados, estando preparados para enfrentar com facilidade problemas inesperados que dependam de uma reorientação nas atividades que realizam, enquanto os países da América Latina sequer possuem sistemas capazes de enfrentar os desafios atuais, tampouco desafios decorrentes da nova onda tecnológica ${ }^{29}$.

Baumgarten (2008), refletindo sobre a interface tecnologia e desenvolvimento social no contexto brasileiro contemporâneo, esboça uma crítica à difundida ideia de que o Brasil carece de se inserir no eixo internacional de desenvolvimento de tecnologias avançadas para, transferindo tal tecnologia ao setor produtivo, alimentar o setor produtivo e conferir competitividade externa ao mercado nacional. Para ela, a noção de progresso da CT é incapaz de satisfazer as demandas de uma sociedade profundamente excludente e desigual, econômica, social e regional, sendo, portanto, inadequada a importação de modelos de PCT prontos.

Dagnino (2008) pontua que nosso modelo de PCT ainda é derivado da noção de neutralidade da CT, o que implica na adesão à busca incessante por inovação e competitividade. Analisa ainda que (DAGNINO, 2009, pp. 112-113):

No novo cenário passa a caber ao Estado e suas instituições (entre elas as universidades públicas) apenas a promoção de um ambiente favorável ou espaços adequados para que os atores que supostamente participariam do processo de inovação (pesquisadores universitários e empresários inovadores ou de base tecnológica) interagissem. Dessa interação, que supostamente iria ser catalisada pela abertura comercial em curso, surgiria a inserção competitiva do país no mercado internacional. As demandas por conhecimento científico e tecnológico associadas às necessidades sociais e à consecução dos objetivos nacionais, cuja satisfação caberia ao Estado promover, deixam de ser consideradas. Ocupam o seu lugar, como vetor da $\mathrm{PCT}$, os interesses vocalizados pela universidade e a empresa privada. No bojo dessa transformação, o grosso da comunidade de pesquisa que não pertence ao "alto clero dos cientistas-empreendedores", acentua seu caráter corporativo. Passa a defender com ardor renovado a ciência básica, levanta a bandeira da "qualidade disciplinar" e, com saudade do passado,

\footnotetext{
${ }^{29}$ Caracterizada como tendo a microeletrônica como elemento central, o que viabiliza baixo custo e baixa demanda energética combinada com enorme capacidade de acumular e processar informação (HERRERA, 1982). 
advoga a manutenção e até o fortalecimento do Modelo Institucional Ofertista Linear para confrontar os que querem a "privatização branca" da universidade, pela via da sua subordinação ao mercado.

Um dos desafios atuais, portanto, se concentra em desmistificar a imagem ingênua de ciência benemérita, promovendo um contrato social diverso, fundado na construção de uma ciência vinculada à dimensão social e necessidades reais da população (NASCIMENTO et al., 2010). Isto passa, necessariamente, por desconstruir a noção de CT autônomas, neutras e orientadas apenas por valores epistêmicos, imunes a valores sociais, econômicos, políticos e culturais;

Outro desafio é definir mecanismos de participação social (HERRERA, 2003) para satisfazer as necessidades locais, que tomam lugar em um contexto histórico e social muito diferente do contexto dos países centrais e que é estruturalmente diferente destes, exigindo inovações pensadas desde este lugar (DAGNINO, 2008).

Sucintamente podemos colocar que o PLACTS, guardadas as especificidades e diversidade expressas sob este acrônimo, compartilha a perspectiva de análise crítica, que oferece uma visão dos problemas do subdesenvolvimento em CT como resultado da dinâmica do sistema de preponderância mundial, no qual a solução de problemas não depende da mera transferência de modelos institucionais, mas sim de ações de gestão e política de CT.

Nesta perspectiva, Vaccarezza (2011) coloca que uma das principais debilidades do desenvolvimento de questões CTS na região é a escassa atenção que recebem os problemas CTS que passam ao largo do processo educativo do indivíduo. Pontua ainda (VACCAREZZA, 2011) que esta tarefa não se restringe a facilitar a compreensão do conteúdo científico das ciências, mas engloba também entender sua dinâmica de produção, de forma que se possa romper a exclusão e fazer com que a sociedade se aproprie do conteúdo e evolução do conhecimento. 


\section{CONSIDERAÇÕES FINAIS}

Trouxemos, durante nosso texto, elementos que foram da caracterização das relações entre ciência, tecnologia e sociedade como algo orgânico e, em certa medida, ontológico para o ser humano, até uma reconstrução histórica dos pontos de inflexão a exemplo do paradigma moderno de ciência e a crítica ao modelo herdado de ciência rumo à desconstrução do modelo linear de desenvolvimento, como pontos que viabilizaram o amadurecimento dos ECTS e a síntese de seus pressupostos nucleares, depositados no silogismo CTS.

Neste percurso, concorreram as visões antigas - aristotélica e platônica, para as quais, sobretudo a platônica, a técnica corresponde a uma forma inferior de conhecimento frente ao episteme. Isto se deve em grande parte à teoria das Ideias de Platão, visão frente a qual o conhecimento da essência das coisas é prejudicado pelos sentidos.

Seguimos adiante para avaliar a evolução sobre as relações entre CTS e reconstruímos o paradigma moderno de ciência, apoiados na noção de que ela é livre de valores (GALILEU, 1987) e seus produtos tecnológicos nos conferem poder sobre a natureza - como queria Francis Bacon. Mais tarde, com Habermas pudemos avaliar este paradigma moderno revisitado, e entender que para este pensador CT devem tornar as decisões políticas suas subordinadas. Acompanhamos ainda o enfraquecimento do paradigma positivista para o qual a ciência obtém resultados empiricamente verificáveis ao seguir um método lógico rígido.

Compreendemos que o movimento que o Programa Forte da Sociologia do Conhecimento e seus sucessores, Programa Empírico do Relativismo e Construção Social da Tecnologia, realizaram uma espécie de travessia, em conjunto com as abordagens etnográficas de Latour e Woolgar, rumo a uma leitura restrita como por 
exemplo, a de Robert Merton, e tirou do domínio exclusivo da própria ciência e da filosofia da ciência a análise do conteúdo das teorias científicas.

Vimos ainda o reflexo de discussões, originalmente empreendidas na Europa (EPOR e SCOT) e América do Norte no contexto Latino-Americano, através do PLACTS, focado em analisar o conceito de desenvolvimento e o papel da política de CT na estrutura do subdesenvolvimento. O PLACTS, por sua vez, evoca uma reflexão sob um prisma socioeconômico e político diferente, que considera as singularidades históricas da América Latina enquanto região periférica e com demandas diferentes das dos países centrais. Neste sentido a contribuição deste texto reside na necessidade de compreender aspectos das relações entre CTS em sua expressão acadêmica, social e suas especificidades no contexto de países periféricos, destacadamente na América Latina e Brasil, não enquanto polaridades, mas enquanto orgânicos e complementares.

Neste sentido situamos a relevância de tentativas como as aqui empreendidas, de avançar no diálogo interdisciplinar - que agregue os historiadores, filósofos, antropólogos e sociólogos da ciência e da tecnologia, aos economistas, analistas da política de CT e gestores de CT; pois parte da premissa de que as ciências humanas sejam um ferramental interpretativo aliado "na busca de análises mais apuradas desta expansão dos objetos tecnológicos para além do espaço laboratorial"'(PREMEBIDA et. al., 2011: 39).

Estes desenvolvimentos apresentados constituem um convite, não apenas para pensar em mecanismos de participação popular em CT mas sobretudo o papel da educação científica neste processo, como destacado por Vaccarezza (2011). É para esta direção que apontamos:para a necessidade de levar estas discussões à sociedade de forma mais ampla, transpondo-as para processos educativos formais e informais, com destaque para o potencial dos primeiros, que viabilizam uma atuação sistemática da comunidade escolar em articulação com a acadêmica e científica e outros atores 
envolvidos no cenário CTS para uma educação em diferentes níveis, mas sempre numa perspectiva de inclusão cidadã e de democratização do acesso a tais debates de forma significativa na conjuntura brasileira atual e que nos permita modificar nossa atuação docente, de pesquisa e extensão.

\section{AGRADECIMENTOS}

Agradeço em especial aos apontamentos do Professor e colega Adelino Cândido Pimenta, pelas sugestões oferecidas a este texto. Agradeço ainda às contribuições de Anna Clara Viana de Oliveira, que também com sua leitura aguçada colaborou para que algumas falhas fossem sanadas.

\section{REFERÊNCIAS}

ABBAgNANO, N. Dicionário de Filosofia. São Paulo: Martins Fontes, 2007.

AIKENHEAD, G. Collaborative Research and Development to Produce an STS Course for School Science. In: SOLOMON, J.; AIKENHEAD, G. STS Education: International Perspectives on Reform. Teachers College Press, New York, 1994a.

STS Education: a rose by any other name. In: CROSS, R. (Ed.). A vision for science education: responding to the work of Peter J. Fensham. New York: Routledge Falmer, 2003. p. 59-75.

. What is STS Science Teaching? In: SOLOMON, J. \& AIKENHEAD, G. STS Education: International Perspectives on Reform. Teachers College Press, New York, $1994 b$.

ARANHA, M. L. A.; MARTINS M.H.P. Filosofando - Introdução à Filosofia. São Paulo: Moderna, 2004.

ARISTÓTELES. Ética a Nicômaco. Tradução de Pietro Nassetti. São Paulo: Ed. Martin Claret, 2007. 
BAUMGARTEN, M. Conhecimento e sustentabilidade: política de ciência,tecnologia e inovação no Brasil contemporâneo. Porto Alegre: Editora da UFRGS/Editora Sulina, 2008. BIJKER, W. E.; PINCH, T. F. The Social Construction ofFacts and Artifacts: Or How the Sociology of Science and the Sociology of Technology Might Benefit Each Other. In: BIJKER, W. E.; HUGHES, T. P.; PINCH, T. F. The Social Construction of Technological Systems - New Directions in the Sociology and History of Technology, Massachusetts: MIT Press, p.17-50, 1989.

BIJKER, W; HUGHES, T.; PINCH, T. The social construction of technological systems New directions in the sociology and history of technology. Cambridge: MIT, 1987.

BLOOR, D. Knowledge and Social Imagery. Chicago: University of Chicago Press, 1991. BRASIL. Ministério da Educação. Coordenação de Aperfeiçoamento de Pessoal de Nível Superior. Plano nacional de pós-graduação (PNPG) 2011-2020-volume I. Brasília: CAPES, 2010.

BUSH, V. Science: The Endless Frontier: A Report to the President by Vannevar Bush, Director of the Office of Scientific Research and Development. Washington, DC: US Government Printing $1945 . \quad$ Office, Disponível em: https://www.nsf.gov/od/lpa/nsf50/vbush1945.htm. Acesso em 18/12/2017.

CANAVARRO, J.M. Ciência e Sociedade. Coimbra: Quarteto Editora, Coleção Nova Era, 1999, 228p.

CARNAP, R. Autobiografía intelectual. Barcelona, Paidós, 1992.

CEREZO, J. A. L.; BAZZO, W. A.; PAlACIOS, E. M. G.; GAlBARTE, J. C. G.; LINSSINGEN, I. V.; LUJÁN, J. L. Introdução aos estudos CTS. Cadernos de IberoAmérica. Ed. OEI, 1, 2003, 170p

CHAUÍ, M. Convite à Filosofia. São Paulo, 13a. ed., Ática, 2003.

COLLINS, H. M. Knowledge and controversy. Social Studies of Science II. ed. 1981. 
. Mudando a ordem: reprodução e indução na prática científica.Tradução Sandra

C. Becker e Pedro Vianna Cava. Belo Horizonte: Fabrefactum Editora, 2011.

COLLINS, H. M; EVANS, R. Repensando a Expertise.Tradução de Igor Antônio L. da Silva. Belo Horizonte: Fabrefactum Editora, 2009.

COMTE, A. Curso de Filosofia primeira; Discurso sobre o espírito positivo (...). Seleção de textos de José Arthur Giannotti e traduções de José Arthur Giannotti e Miguel Lemos. São Paulo: Abril Cultural, 1978 (Coleção Os Pensadores).

CUNHA, A. M. Ciência, Tecnologia e sociedade na Ótica Docente: Construção e Validação de uma Escala de Atitudes. 2008. 103p. Dissertação (Mestrado em Educação) - Universidade Estadual de Campinas, Campinas, 2008. Disponível em http://repositorio.unicamp.br/jspui/handle/REPOSIP/252114. Acesso em 20/08/2017.

CURD, P. Presocratic Philosophy. The Stanford Encyclopedia of Philosophy (Winter 2016 Edition), Edward N. Zalta (ed.).

CUTCLIFFE, S.H. Ciencia, Tecnología y Sociedad: un campo interdisciplinar. In: MEDINA, M.; SANMARTín, J. (eds.): Ciencia, Tecnología y Sociedad, pp. 20-41. Barcelona: Anthropos, 1990.

DAGNINO, R. A relação universidade-empresa no Brasil e o "argumento da hélicetríplice". Revista Brasileira de Inovação. v. 2. n. 2. Julho. Brasília, 2003.

- Ciência e Tecnologia no Brasil: o processo decisório e a comunidade de pesquisa. Campinas: Editora da Unicamp, 2007.

.Neutralidade da Ciência e Determinismo Tecnológico: um debate sobre a tecnociência. Campinas: Editora da Unicamp, 2008

. O que é o PLACTS (Pensamento Latino-americano em Ciência,Tecnologia e Sociedade)? Revista Tecnologia \& Sociedade. Ângulo 140, Jan./Mar., 2015. p. 6. 
. A construção do Espaço Ibero-americano do Conhecimento, os estudos sobre ciência, tecnologia e sociedade e a política científica e tecnológica. Rev. iberoam. cienc. tecnol. soc., Ciudad Autónoma de Buenos Aires, v. 4, n. 12, p. 93-114, abr. 2009.

DUARTE, T. R. O Programa Forte e a Busca de uma Explicação Sociológica das Teorias Científicas: Constituição, Propostas e Impasses. 2007. 100p. Dissertação (Mestrado em Sociologia) Belo Horizonte: Faculdade de Filosofia e Ciências Humanas da UFMG, 2007.

ESQUINA, M. F., TORRES ALBERTO, C. La ciencia como institución social: clásicos y modernos institucionalismos en la Sociología de la Ciencia. Arbor: Ciencia, Pensamiento y Cultura, v. 185, n. 738, p. 663-687, jul. ago. 2009. Disponível em: http://arbor.revistas.csic.es/index.php/arbor/article/view/323

FOUREZ, G. A construção das ciências: introdução à filosofia e à ética das ciências. São Paulo: UNESP/FUNDUNESP, 1995.

FREITAG, B. A teoria crítica: ontem e hoje. São Paulo: Brasiliense, 1986. . Habermas e a teoria da modernidade. ", Cadernos CRH, №. 22, Jan./Jun., p. 138-163, 1995.

GALILEU, G. O ensaiador. São Paulo: Nova Cultural, 1987. p. VI-X. (Os pensadores). GARCíA, M. I. G.; CEREZO, J. A.L.; LUJÁN, J. L. Ciência, tecnologia y sociedad. Una introducción al estudio social de la ciencia y la tecnología. Madrid: Tecnos, 1996.

HABERMAS, J. Teoria de la accióon comunicativa: complementos y estúdios prévios. Madrid; Cátedra, 1989. (Edição espanhola)

. Modernidade - um projeto inacabado. In: ARANTES, O. B. F.; ARANTES, P. E. Um ponto cego no projeto moderno de Jürgen Habermas: arquitetura e dimensão estética depois das vanguardas. São Paulo: Brasiliense, 1992.

.Técnica e ciência enquanto ideologia. São Paulo: Abril Cultural, 1980. 
. Vorstudien und Erganzungen pur theorie des kommunikativen Handelns.

Frankfurt/M., Suhrkamp Verlag, 1984.

HERRERA, A. Novo enfoque do desenvolvimento e o papel da ciência e da tecnologia. In: DAGNINO, R.; THOMAS, H. Ciência, Tecnologia e Sociedade: uma reflexão latino-americana. Taubaté: Cabral Editora e Livraria Universitária, 2003.

. Prospectiva Científica e Tecnológica para a América Latina. São Paulo, FAUUSP, 1982. (Seminário Tecnologias apropriadas para os assentamentos humanos).

HESSEN, B. As raízes socioeconômicas dos Principia de Newton. In: GAMA, Ruy (org.). Ciência e técnica: antologia de textos históricos. São Paulo: T. A. Queiroz, 1992, p. 3089.

JAEGER, W. W. Paidéia: a formação do homem grego. Trad. Artur M. Parreira. 4ạ Ed. São Paulo: Martins Fontes, 2001.

KOYRÉ, A. Do mundo fechado ao universo infinito. Brasília: Forense Universitária, 1979.

KROPF, S. P.; FERREIRA, L. O. A prática da ciência: uma etnografia no laboratório. Resenha do livro "Vida de laboratório", de Bruno Latour e Steve Woolgar (1997). Rio de Janeiro: História, Ciência, Saúde - Manguinhos. Casa de Oswaldo Cruz, 1998 (Resenha). Disponível em <http://www.scielo.br/pdf/hcsm/v4n3/v4n3a10>

KUHN, T. S. A estrutura das revoluções científicas. São Paulo: Pespectiva, 2003.

LATOUR, B.; WOOLGAR, S. A vida de laboratório: a produção de fatos científicos. Tradução de Angela R. Vianna. Rio de Janeiro: Editora Relume Dumará, 1997;

LAUDAN, L. The Pseudo-Science of Science?. In: Brown, James R. Scientific Rationality: The Sociological Turn. Dordrecht: D. Reidel Publishing Company, 41-73, 1984.

MARCOVICH, A.; SHINN, T. Robert K. Merton, fundados da sociologia da ciência: comentários, insights, críticas. In: MERTON, R. K. Ensaios de Sociologia da Ciência. 
Tradução de Sylvia G. Garcia e Pablo R. Mariconda. São Paulo: Editora 34, p.253-291, 2013.

MARICONDA, P.; LACEY, H. A águia e os estorninhos. Galileu e a autonomia da ciência.Tempo Social; Rev. Sociol. USP, S. Paulo, 13(1): 49-65, 2001.

MARTINS, H. Tecnologia, modernidade e política. Lua Nova, São Paulo, n. 40-41, p. 279-322, Aug. 1997

Disponível

em

<ttp://www.scielo.br/scielo.php?script=sci_arttext\&pid=S0102-

64451997000200013\&lng=en\&nrm=iso. Acesso em 19 Set. 2017.

MATTOS, C. L. G. A abordagem etnográfica na investigação científica. In MATTOS, CLG., and CASTRO, PA., orgs. Etnografia e educação: conceitos e usos [online]. Campina Grande: EDUEPB, 2011. pp. 49-83.

MEDINA, M. De la ciencia moderna a la tecnociencia en acción. 2008. Disponível em:http://www.c3si.org/invescit/publicaciones/DelaCMaTC.pdf

MEDINA, M.; SANMARTÍN, J. (eds.): Ciencia, Tecnología y Sociedad, pp. 42-75. Barcelona: Anthropos, 1990.

MERTON, R. K. Ensaios de Sociologia da Ciência. Tradução de Sylvia G. Garcia e Pablo R. Mariconda. São Paulo: Editora 34, 2013.

MITCHAM, C. In search of a new relation between science, technology, and society. Technology in society. 1989.

Why science, technology, and society studies?. Bulletin of Science, Technology \& Society, 1999.

NASCIMENTO, F.; FERNANDES, H. L.; MENDONÇA, V. M. O ensino de ciências no Brasil: história, formação de professores e desafios atuais. Revista HISTEDBR On-line, [S.I.], v. 10, n. 39, p. 225-249, ago. 2012. ISSN 1676-2584. Disponível em: https://periodicos.sbu.unicamp.br/ojs/index.php/histedbr/article/view/8639728.

Acesso em: 16 set. 2017. 
PALÁCIOS, M. O Programa Forte de Sociologia do Conhecimento e o princípio da causalidade. In: PORTOCARRERO, V. (Org.). Filosofia, história e sociologia das ciências I: abordagens contemporâneas. Rio de Janeiro: Editora FIOCRUZ, 1994. p. 175-198. Disponível em: SciELO Books: http://books.scielo.org. F

PARSONS, T. The Structure Of Social Action. Nova York: The Free Press, 1937.

PARTENIE, C. Plato's Myths. The Stanford Encyclopedia of Philosophy (Summer 2014 Edition), Edward N. Zalta (ed.).

PESSANHA, J. A. M. Galileu: vida e obra. In GALILEI, Galileu. O ensaiador. São Paulo: Nova Cultural, 1987. p. VI-X. (Coleção Os pensadores).

POPPER, K. A lógica da pesquisa científica. São Paulo: CULTRIX, 1974.

PREMEBIDA, A.; NEVES, F. M.; ALMEIDA, J. Estudos sociais em ciência e tecnologia e suas distintas abordagens. Sociologias, Porto Alegre, ano 13, no 26, jan./abr. 2011, p. $22-42$

REALE, G; ANTISERI, D. História da filosofia: Antiguidade e Idade Média. São Paulo: Paulus, 1990. (Coleção Filosofia)

RIGOLIN, C. Observatório em CT\&I - Ciência, Tecnologia e Inovação em Saúde. 2016;

Tema: Metodologia de Estudos Sociais da Ciência e Tecnologia: uma síntese. Disponível em: <http://observatorio.fiocruz.br/ponto-de-vista/metodologias-depesquisa-de-estudos-sociais-de-ciencia-e-tecnologia>

RUSSELL, B. Logical Positivism. In: Robert Charles Marsh (ed.): Logic and Knowledge Essays 1901 -1950. Lonfres: George Allen \& Unwin LDT/ Nova York: The Macmillan Company, p 367-382, 1971.

SÁBATO, J., MACKENZIE, M. La producción de tecnología. Ed. Nueva Imagen, México, 1982. 
SILVA, F. L. Conhecimento e Razão Instrumental. Psicol. USP, São Paulo, v. 8, n. 1, p. 11-31, 1997.

SNOW, C.P. As duas culturas e uma segunda leitura: uma versão ampliada das duas culturas e a revolução científica.São Paulo: Editora da USP, 1995.

SOLOMON, J. Science technology and society courses: Tools for thinking about social issues. International Journal of Science Education, v. 10, n. 4, p.379-387, 1988

SUÁREZ, F. Los economistas argentinos. El proceso de institucionalización de nuevas profesiones. EUDEBA, Buenos Aires, 1973.

TRIGUEIRO, M. G. S. Ciência, Verdade e Sociedade: contribuições para um diálogo entre Sociologia e a Filosofia da Ciência. Belo Horizonte: Editora Fabrefactum, 2012.

VACCAREZZA, L. S. Ciencia, tecnología y sociedad: el estado de la cuestión en AméricaLatina.Revist@ do Observatório do Movimento pela Tecnologia Social da América Latina. v. 01, 42 - 642011.

VARSAVSKY, O. Ciencia, política y cientificismo. Buenos Aires: CEAL, 1978.

. Proyectos nacionales. Planteos y estudios de viabilidad. Ediciones Periferia, Buenos Aires, 1971.

von LINSINGEN, I. Perspectiva educacional CTS: aspectos de um campo em consolidação na América Latina. Ciência \& Ensino. 